\title{
Food spectrum and trophic structure of the ichthyofauna of Corumbá reservoir, Paraná river Basin, Brazil
}

\author{
Karla D. G. Luz-Agostinho*, Luis M. Bini**, Rosemara Fugi*, \\ Angelo A. Agostinho, and Horácio F. Júlio Jr.*
}

In this paper we evaluate plasticity of fish concerning diet. We expect that sampling over a large temporal and spatial scale, including environmental changes such as impoundments, will allow us to cover most of the diet plasticity. We also evaluate the efficacy of ordination method in discriminating trophic groups based on fish species diet. Data were obtained from 17 sampling stations sampled monthly from March/96 to February/99 in the Corumbá river drainage, before and after the formation of the Corumba reservoir. Diet was determined analysing 9,177 stomach contents from 64 fish species. Trophic categories were discriminated by a non-hierarchic grouping analysis named $k$-means, applied to diet data. Most of the species presented great trophic plasticity, eating a great variety of food items. Resources availability, estimated from all fish stomach contents, was similar among environments, except in creeks, where it varied more with a large importance of terrestrial insects. $K$-means present satisfactory results, identifying nine trophic groups (detritivores, herbivore-piscivores, insectivore-herbivores, omnivores, invertivores, aquatic insectivores, piscivore-insectivores, piscivores and herbivores).

Neste estudo avaliamos a plasticidade trófica em peixes. Nós esperamos que amostras obtidas com uma ampla escala temporal e espacial, incluindo mudanças ambientais como represamentos, nos permita cobrir a maior parte desta plasticidade. Foi avaliada também a eficiência do método de ordenação em discriminar os grupos tróficos baseado na dieta das espécies. As amostragens foram realizadas mensalmente de março/96 a fevereiro/99 em 17 estações de coleta na bacia do rio Corumbá antes e após a formação do reservatório de Corumbá. Foram analisados 9177 conteúdos estomacais, pertencentes a 64 espécies. As categorias tróficas foram discriminadas através de uma análise de agrupamento não hierárquica denominada $K$-means aplicada aos dados de dieta. A maioria das espécies apresentou elevada plasticidade trófica, consumindo uma grande variedade de itens alimentares. A disponibilidade dos recursos alimentares, estimada através de todos os conteúdos estomacais, foi similar entre os ambientes a exceção dos riachos, onde ocorreu maior heterogeneidade e os insetos terrestres tiveram grande importância. A análise $K$-means revelou resultados satisfatórios, identificando nove grupos tróficos (detritívoros, herbívoro-piscívoros, insetívoro-herbívoros, onívoros, invertívoros, insetívoros aquáticos, piscívoro-insetívoros, piscívoros e herbívoros).

Key words: fish diet, feeding plasticity, resources availablility.

\section{Introduction}

During the colonization process of a reservoir, some populations are depleted, while others show explosive growth in response to rapid environmental changes (Agostinho, 1992; Agostinho et al., 1997). The abrupt transformations in water dynamics lead to modifications in environmental conditions, altering biotic interactions and food resource proportions (Hahn et al., 1997a). Consequently, food supply appears to be an important indicator of species success during the occupation of a new environment (Paiva, 1983; Petts, 1984; Rodríguez-Ruiz, 1998).
Although some fishes in tropical environments present marked trophic specializations, most exhibits great feeding flexibility (Agostinho et al., 1995; Araújo-Lima et al., 1995; LoweMcConnell, 1999). Trophic plasticity can be an important strategy that allows the use of abundant available food resources at the beginning of reservoir formation. However, the initial abundant food resources (especially allochthonous) tend to decrease after the first years of the impoundment (Petrere Jr \& Ribeiro, 1994; Agostinho et al., 1999), promoting population alterations that are reflected in the assemblage structure.

Then, describing trophic structure of fish assemblages and understanding feeding relationships among organisms

\footnotetext{
*Núcleo de Pesquisas em Limnologia, Ictiologia e Aqüicultura, Universidade Estadual de Maringá. Maringá, PR, Brazil. e-mail: karla.dgl@uol.com.br

**Departamento de Biologia Geral, Universidade Federal de Goiás, Goiânia, GO, Brazil. e-mail: bini@icb1.ufg.br
} 
is fundamental for an effective conservation and management of the fish fauna. Data on fish assemblage diet over spatial and temporal scales, covering all ontogenetic species stages, supplies important information on resources availability (Winemiller, 1996) and on the use of those resources (Agostinho et al., 1997).

In this paper we evaluate plasticity of fish concerning diet. We expect that sampling over a large temporal and spatial scale, including environmental changes (formation of the Corumbá reservoir), we will be able to cover most of the diet plasticity. We also evaluate the efficacy of ordination method in discriminating trophic groups based on fish species diet.

Study area.The Corumbá river (Goiás State) is the main rightbank tributary of the Paranaíba river (Fig. 1) that, together with the Grande river, originates the Paraná river. Its drainage basin has an area of $34,000 \mathrm{~km}^{2}$ (predominantly scrubland in the Cerrado Biome). It is an upland river and the largest part of its course is narrow, with rocky bed and steep banks (Paiva, 1982). The Corumbá river was dammed in September 1996, forming the Corumbá Hydroelectric Reservoir. Corumbá Res-

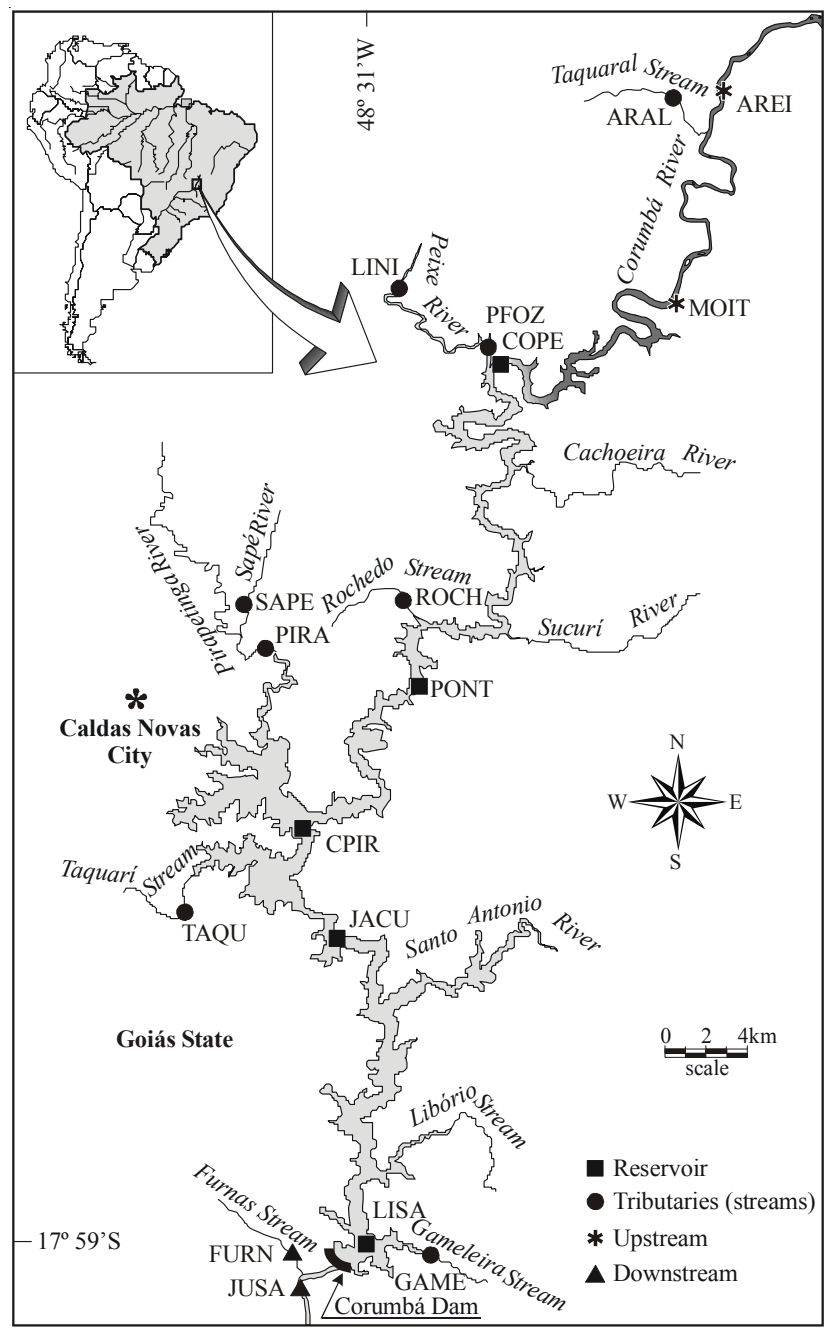

Fig. 1. Studied area. Map of the Corumbá river, where the Corumbá reservoir was formed, showing the sampling stations. ervoir presents a surface area of $65 \mathrm{~km}^{2}$, a total volume of 1500 $\mathrm{x} 10^{6} \mathrm{~m}^{3}$, an average depth of $23 \mathrm{~m}$ and a hydraulic retention time of 30 days.

\section{Materials and Methods}

Fish samples were carried out monthly from March 1996 to August 1996 (river phase), September 1996 to February 1997 (filling phase) and March 1997 to February 1999 (reservoir phase) in 17 sites distributed in the lower Corumbá river basin and its tributaries. Sample sites were grouped in streams (sampling stations FURN, GAME, TAQU, ROCH and ARAL), river upstream (AREI and MOIT), river downstream (JUSA), reservoir (LISA, JACU, PONT, CPIR and COPE) and medium sized streams (LINI, PFOZ, PIRA and SAPE) herein named biotopes (Fig. 1). Fish were collected by a set of gillnets with different mesh sizes (between 2.4 and $16.0 \mathrm{~cm}$ opposite knots). Nets were set in open areas during 24 hours (checked at 08:00, 16:00 and 22:00). In littoral areas, $20 \mathrm{~m}$-long seining nets ( 0.5 $\mathrm{cm}$ mesh size) were operated during the day and night. In streams, electrofishing was conducted using a $220 \mathrm{v}$ generator equipped with 50-meter cables and two energized dip nets.

All collected fish were identified and stomachs with content were removed and preserved in $4 \%$ formalin, and later transferred to $70 \%$ alcohol for laboratory analysis. Voucher specimens were deposited in the Ichthyological Collection of the Núcleo de Pesquisas em Limnologia, Ictiologia e Aquicultura of the Universidade Estadual de Maringá (CINupelia-UEM).

Stomach contents were examined under a stereoscopic microscope and identified to the lowest taxonomic level possible. To express diet results, we used volumetric (obtained by water displacement in graduated beaker) and occurrence frequency methods (Hynes, 1950; Hyslop, 1980) combined in the Alimentary Index (IAi) proposed by Kawakami \& Vazzoler (1980), described by the equation:

$$
\mathrm{IAi}=\frac{\mathrm{F}_{\mathrm{i}} * \mathrm{~V}_{i}}{\sum_{\mathrm{n}=1}^{\mathrm{n}}\left(\mathrm{F}_{\mathrm{i}} * \mathrm{~V}_{\mathrm{i}}\right) \times 100}
$$

Where: $\mathrm{IAi}=$ alimentary index $; \mathrm{i}=1,2, . ., \mathrm{n}$ food item; $\mathrm{Fi}=$ occurrence frequency percentage and $\mathrm{Vi}=$ volumetric frequency percentage.

Food spectrum and resource availability. Food spectrum and the importance of each item to the diet were established according to the alimentary index values obtained for the entire sampling period considering all sampled biotopes. Spatial variation in the availability of resources was analyzed only after the filling of the reservoir (March 1997 to February 1999).

Resource availability was inferred from the volume of food items in the stomachs analyzed for all species combined. Inferences of this type assume that captured species exploit all resources in the environment that are susceptible to ingestion (Lawlor, 1980; Winemiller, 1989; Winemiller \& Kelso- 
Winemiller, 1996). Although this assumption may lead to distortions (e.g. food items with different degrees of digestibility), it should produce results that are closer to reality than the alternative method, i.e. quantification of various food resources in the environment based on different sampling methodologies that generate non-comparable data on resource abundances. In this study, due to the fact that contents analysis were restricted to sub-samples, volumes of the items were corrected by the ratio of the species in the sample, considering only individuals with food in their stomach, according to the equation:

$$
D=\sum_{n=1}^{s}\left(V_{i} \cdot n_{i} / N\right)
$$

Where: $D=$ item availability $V_{i}=$ item volume for species $i$; $n_{i}=$ number of individuals in species $i$ with stomach content; $N=$ total number of individuals with stomach content in the sample; $\mathrm{s}=$ species number.

Ordination and trophic classification of the species based on diet. In order to classify species into trophic groups, we first ordinated the data using a Detrended Correspondence Analysis (DCA; Hill \& Gauch, 1980; Gauch, 1994). DCA ordination allowed the analysis of the patterns of feeding similarity among the 52 species based on IAi values, which were squareroot transformed, before analysis, to reduce skewness. Second, we identified trophic groups based on the scores of first two DCA axes with a nonhierarchical cluster analysis, the $k$ means method (STATISTICA 5.5; STASOFT, 2000). The number of groups was determined following Bussab et al. (1990).

\section{Results}

Food spectrum and availability of resources. A total of 9,177 stomachs representing 64 fish species presented some type of food (Table 1). However, diet characterization was carried out only for species with more than 10 stomachs with identifiable food items, resulting in a data set of 9,139 stomachs representing 52 species. Intake food resources were grouped in: microcrustaceans (cladocerans, copepods, ostracods and conchostracans), aquatic insects (dipterans, ephemeropterans, odonats, tricopterans, hemipterans, coleopterans and plecopterans), terrestrial insects (dipterans, hymenopterans, coleopterans, isopterans, ortopterans, homopterans, neuropterans, odonats, lepidopterans and hemipterans), other aquatic invertebrates (acarines, bryozoans, bivalves, nematodes, testate amoebae, oligoquetes, rotifers and decapods.), other terrestrial invertebrates (diplopods, araneans, isopods, oligoquetes, gastropods), fish (characiformes, siluriformes, cypriniformes, gymnotiformes and perciformes), other vertebrates (amphibians), algae (filamentous and unicellular), aquatic plants (bryophytes, macrophyte parts), terrestrial plants (seeds, fruits, higher plant leaves), and detritus/sediment (amorphous organic material with an elevated content of mineral particles). Most of the species presented great trophic flexibility, evidenced by the incorporation of a wide variety of food resources in their diets.

The most widely consumed food resources were aquatic insects (mainly dipterans; eaten by 55 species - $85.9 \%$ of the total number of analyzed species), terrestrial plants (47 species - 73.4\%), detritus/sediment (46 species - $71.9 \%$ ), terrestrial insects (mainly hymenopterans; 44 species - 68.7\%), fish (mainly Characiformes; 41 species - 64.1\%), algae (mainly Chlorophyceae; 32 species $-50.0 \%$ ). In addition, other aquatic invertebrates ( 25 species - $39.1 \%$ ), microcrustaceans (21 species - $32.8 \%$ ), aquatic plants (14 species - $21.9 \%$ ), other terrestrial invertebrates (11 species - 17.2\%) and other vertebrates ( 2 species $-3.1 \%$ ), were also important.

The availability of these resources in the different biotopes (inferred from the volume of the food items ingested by all species) showed similar tendencies, with fish and terrestrial plants being the most available resources (Fig. 2). However, in streams, there were more available resources, with greater importance of terrestrial insects. In the reservoir and river sections, fish constituted the basic food source. Notwithstanding, high occurance of aquatic insects were found in fish stomachs from all environments.

Ordination. The coefficient of determination between distances in the ordination space and distance in the original space, for the first axis of the DCA (eigenvalue $=0.48$ ) was equal to 0.66 . This indicates that the first axis expresses most

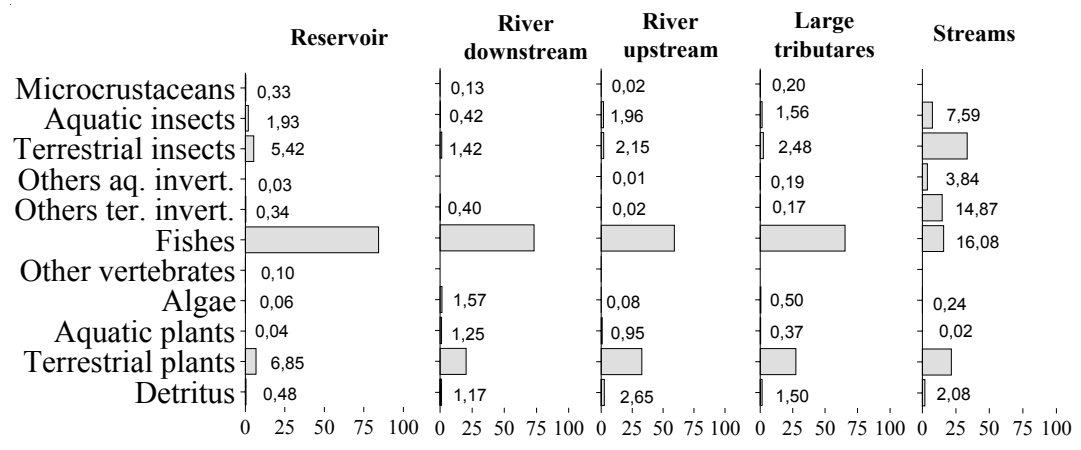

Volume (\%)

Fig. 2. Food resource availability, inferred from the volume of food items in the stomachs analyzed for all species combined. 
Table I. Main food resources (IAi \%) consumed by fish species of the Corumbá river basin, combined for the entire sampling period and different biotopes ( $1=$ microcrustaceans; $2=$ aquatic insects; $3=$ terrestrial insects; $4=$ others aquatic invertebrates; $5=$ other terrestrial invertebrates; $6=$ fishes; $7=$ other vertebrates; $8=$ algae; $9=$ aquatic plants; $10=$ terrestrial plants; $11=$ detritus). $C=$ species codes used at Figure 3; N=number of stomach contents analysed. See Trophic structure for characterization of the groups.

\begin{tabular}{|c|c|c|c|c|c|c|c|c|c|c|c|c|c|c|}
\hline Species & $\mathrm{C}$ & Common Name & $\mathrm{N}$ & 1 & 2 & 3 & 4 & 5 & 6 & 7 & 8 & 9 & 10 & 11 \\
\hline \multicolumn{15}{|c|}{ GROUP 01 - DETRITIVORES } \\
\hline$\overline{\text { Apareiodon affinis }}$ & 1 & "canivete" & 169 & 0.03 & 10.16 & - & 0.01 & 0.04 & 0.01 & - & 17.24 & - & 0.13 & 72.32 \\
\hline Apareiodon piracicabae & 6 & "canivete" & 69 & 0.04 & 6.66 & - & 0.05 & - & - & - & 11.34 & 1.52 & 0.74 & 79.65 \\
\hline Hypostomus regani & 22 & "cascudo" & 111 & - & 0.30 & 0.19 & - & - & - & - & 3.36 & 0.01 & 0.49 & 95.64 \\
\hline Hypostomus sp. & 23 & "cascudo" & 19 & 0.01 & 0.15 & - & - & - & - & - & 9.50 & 1.45 & - & 88.88 \\
\hline Prochilodus lineatus & 41 & "curimbatá" & 150 & - & 0.02 & - & 0.07 & - & - & - & 2.05 & - & 1.58 & 96.28 \\
\hline Steindachnerina corumbae & 46 & "saguiru" & 289 & 0.07 & 0.43 & 0.04 & 0.01 & - & - & - & 3.65 & 0.01 & 0.48 & 95.32 \\
\hline Steindachnerina insculpta & 47 & 'saguiru" & 395 & 0.02 & 1.22 & 0.07 & 0.01 & - & - & - & 1.93 & - & 0.13 & 96.62 \\
\hline \multicolumn{15}{|c|}{ GROUP 02 - HERBIVORE-PISCIVORES } \\
\hline Astyanax bimaculatus & 2 & "tambiú" & 695 & 0.12 & 5.09 & 15.67 & - & 0.08 & 10.23 & - & 0.03 & - & 68.70 & 0.09 \\
\hline Astyanax fasciatus & 4 & "lambari" & 427 & 0.04 & 24.16 & 14.29 & - & - & 0.39 & - & 0.05 & - & 60.97 & 0.10 \\
\hline Leporinus friderici & 27 & "piau" & 635 & - & 0.25 & 0.06 & - & - & 76.49 & - & 0.04 & - & 22.80 & 0.35 \\
\hline Leporinus octofasciatus & 28 & "ferreirinha" & 49 & - & 1.97 & 6.28 & - & - & 16.36 & - & 0.02 & - & 74.68 & 0.68 \\
\hline \multicolumn{15}{|c|}{ GROUP 03 - INSECTIVORE-HERBIVORES } \\
\hline Astyanax eigenmanniorum & 3 & "lambari" & 107 & - & 59.04 & 27.43 & - & - & 0.01 & - & 5.51 & 0.19 & 4.55 & 3.27 \\
\hline Leporinus elongatus & 26 & "piapara" & 166 & - & 77.78 & - & - & 0.17 & 0.73 & - & 0.07 & - & 14.34 & 6.90 \\
\hline Odontostilbe sp. & 37 & "pequira" & 37 & 0.03 & 43.27 & 4.89 & 0.02 & - & 1.49 & - & 41.41 & 0.52 & 6.28 & $2.06-$ \\
\hline \multicolumn{15}{|c|}{ GROUP 04 - OMNIVORES } \\
\hline Apareiodon ibitiensis & 5 & "canivete" & 51 & - & 93.08 & 0.04 & - & - & 2.16 & - & 1.24 & 0.60 & 2.75 & 0.12 \\
\hline Astyanax scabripinnis paranae & 7 & "lambari" & 100 & - & 19.46 & 46.34 & 0.16 & - & 0.06 & 0.96 & - & - & 32.96 & 0.06 \\
\hline Brycon nattereri & 8 & "pirapitinga" & 25 & - & 17.20 & 67.43 & 0.06 & - & 0.27 & - & 0.23 & - & - & 2.70 \\
\hline Bryconamericus stramineus & 9 & "pequira" & 390 & - & 67.69 & 27.93 & 0.02 & 0.04 & 1.54 & - & 0.14 & 0.32 & 2.09 & 0.23 \\
\hline Crenicichla haroldoi & 11 & "joaninha" & 36 & - & 87.87 & 3.82 & 0.01 & - & 2.37 & - & - & - & 5.93 & - \\
\hline Moenkhausia intermedia & 31 & "pequi" & 276 & 6.59 & 76.44 & 9.57 & - & - & 1.58 & - & 0.13 & - & 4.66 & 1.03 \\
\hline Piabina argentea & 38 & "pequira" & 894 & 0.02 & 67.07 & 8.18 & 0.09 & 0.03 & 0.43 & - & - & 0.01 & 22.21 & 1.96 \\
\hline & & & & ROUP & $05-$ IN & ERTIV & DRES & & & & & & & \\
\hline Corydoras sp. & 16 & "coridoras" & 37 & 1.31 & 89.01 & 0.01 & 3.23 & - & - & - & - & - & - & 5.86 \\
\hline Eigenmannia sp. & 17 & "tuvira" & 37 & 0.02 & 90.53 & 0.35 & 0.14 & - & 0.18 & - & - & - & 0.10 & 8.68 \\
\hline Gymnotus carapo & 18 & "morenita" & 24 & - & 65.76 & 12.35 & - & - & 0.50 & - & - & - & - & 21.39 \\
\hline Iheringichthys labrosus & 24 & "mandi-beiçudo" & 441 & 0.25 & 77.07 & 0.34 & 0.14 & 0.01 & 0.08 & - & 0.04 & - & 0.45 & 21.64 \\
\hline Leporinus amblyrhynchus & 25 & "canivete" & 195 & 0.16 & 78.86 & 0.15 & 0.80 & 0.06 & 0.03 & - & - & 0.01 & 0.93 & 19.00 \\
\hline Oreochromis niloticus & 35 & "tilápia" & 14 & 0.60 & 54.16 & 0.03 & 0.02 & - & - & - & 1.17 & - & - & 44.02 \\
\hline Sternopygus macrurus & 48 & "tuvira" & 11 & - & 90.12 & 0.18 & - & - & - & - & - & - & 0.30 & 9.39 \\
\hline & & & GROL & $06-$ & AQUAT & C INSE & CTIVOR & & & & & & & \\
\hline Bryconamericus sp. & 10 & "pequira" & 104 & - & 92.57 & 6.75 & - & - & 0.29 & 0 & 0.16 & - & - & 0.09 \\
\hline Cetopsorhamdia iheringi & 12 & "mandizinho" & 39 & - & 98.53 & 1.03 & - & - & - & - & - & - & - & 0.43 \\
\hline Characidium zebra & 15 & "canivete" & 23 & - & 89.68 & 0.07 & - & - & 3.81 & - & - & 6.35 & 0.10 & - \\
\hline Glanidium cesarpintoi & 19 & "jundiá" & 25 & - & 77.82 & 21.70 & 0.36 & - & - & - & - & - & 0.12 & - \\
\hline Leporellus vittatus & 30 & "solteira" & 16 & - & 99.81 & - & - & - & - & - & - & - & 0.16 & 0.03 \\
\hline Tatia neivai & 52 & "jundiá" & 52 & - & 79.30 & 20.07 & - & - & 0.06 & - & 0.03 & - & 0.12 & 0.43 \\
\hline & & & ROU & $07-1$ & ISCIVO & 2E-INSE & CTIVOI & ES & & & & & & \\
\hline Megalonema platanus & 32 & "pati" & 17 & - & 54.66 & 1.46 & - & - & 42.77 & - & - & - & 0.92 & 0.18 \\
\hline Oligosarcus planaltinae & 36 & "cadela" & 31 & - & 19.34 & 1.99 & 0.04 & - & 76.46 & - & 0.04 & - & 0.05 & 2.07 \\
\hline Pimelodus fur & 40 & "mandi" & 41 & 0.02 & 43.13 & 23.44 & - & - & 27.17 & - & 0.02 & - & 5.31 & 0.92 \\
\hline Pimelodus maculatus & 42 & "mandi" & 486 & 0.11 & 3.95 & 17.05 & 0.03 & 0.43 & 74.77 & - & - & - & 3.31 & 0.34 \\
\hline Pimelodus paranensis & 43 & "mandi" & 47 & - & 14.74 & 5.47 & 0.02 & - & 79.75 & - & - & - & 0.02 & 0.01 \\
\hline Pimelodella sp. & 44 & "mandi-chorão" & 107 & - & 26.25 & 1.53 & 0.01 & 0.06 & 59.21 & - & - & - & 12.71 & 0.27 \\
\hline & & & & ROU & $08-P$ & ISCIVOI & RES & & & & & & & \\
\hline$\overline{\text { Cichla monoculus }}$ & 13 & "tucunaré" & 106 & 0.06 & - & 0.01 & - & - & 99.93 & - & - & - & - & - \\
\hline Cichlasoma paranaense & 14 & "cará" & 20 & - & 0.94 & - & 0.04 & 0.12 & 98.79 & - & - & - & - & 0.11 \\
\hline Galeocharax knerii & 20 & "peixe-cadela" & 1104 & - & - & - & - & - & 99.99 & - & - & - & 0.01 & - \\
\hline Hoplias malabaricus & 21 & "traíra" & 128 & - & - & 0.02 & - & - & 99.97 & - & - & - & - & - \\
\hline Pseudoplatystoma corruscans & 39 & "pintado" & 14 & - & - & 0.01 & - & - & 99.99 & - & - & - & - & - \\
\hline Rhamdia quelen & 45 & "bagre" & 88 & - & 0.44 & 2.20 & - & 0.13 & 97.00 & - & - & - & 0.21 & 0.02 \\
\hline Salminus maxillosus & 49 & "dourado" & 220 & - & 0.01 & - & - & - & 99.99 & - & - & - & - & - \\
\hline Serrasalmus spilopleura & 51 & "piranha" & 56 & - & - & - & - & - & 99.63 & - & - & - & 0.37 & - \\
\hline & & & & $\mathbf{O L}$ & 09-H & RBIVO & RES & & & & & & & \\
\hline Lebistes reticulatus & 29 & "guaru" & 26 & - & 1.58 & 0.01 & - & - & - & - & 0.01 & - & 81.83 & 16.56 \\
\hline Myloplus tiete & 33 & "pacu-prata" & 134 & - & 0.11 & 0.01 & - & - & 0.03 & - & 0.02 & 0.04 & 99.79 & 0.01 \\
\hline Metynnis sp. & 34 & "pacu" & 34 & - & - & - & - & - & 0.01 & - & 0.92 & - & 98.63 & 0.44 \\
\hline Schizodon nasutus & 50 & "ximborê" & 372 & - & 0.01 & - & - & - & 0.02 & - & 0.27 & 0.17 & 99.36 & 0.17 \\
\hline & & & & $\mathbf{O U I}$ & $\mathbf{N D}-\mathbf{N}$ & OT DEF & INED & & & & & & & \\
\hline Ageneiosus valenciennesi & - & "manduvê" & 1 & - & - & - & - & - & - & - & 100 & - & - & - \\
\hline Characidium gomesi & - & "canivete" & 1 & - & 54.17 & 15.83 & 10.83 & - & - & - & - & - & 19.17 & - \\
\hline Cyphocharax modestus & - & "saguiru" & 3 & - & 100 & - & - & - & - & - & - & - & - & - \\
\hline Hasemania hanseni & - & "lambarizinho" & 5 & - & 95.84 & - & - & - & 2.08 & - & - & - & 2.08 & - \\
\hline Hoplosternum littorale & - & "tamboatá" & 7 & 0.08 & 88.40 & 0.01 & 0.01 & - & - & - & - & - & 0.34 & 11.15 \\
\hline Neoplecostomus paranensis & - & "cascudinho" & 2 & - & - & - & - & - & - & - & - & - & 100 & - \\
\hline Nannorhamdia schubarti & - & "bagrinho" & 3 & - & 8.23 & - & - & - & - & - & 4.11 & - & 87.64 & 0.02 \\
\hline Porotergus ellisi & - & "ituí-cavalo" & 4 & 3.78 & 93.57 & 2.65 & - & - & - & - & - & - & - & - \\
\hline Paradon tortuosus & - & "canivete" & 4 & - & - & - & - & - & - & - & 97.46 & - & 0.17 & 2.37 \\
\hline Rhinodoras dorbignyi & - & "armado" & 2 & - & 66.72 & - & - & - & - & - & - & - & 33.28 & - \\
\hline Salminus hilarii & - & "tabarana" & 2 & - & - & - & - & - & 100 & - & - & - & - & - \\
\hline Tilapia rendalli & - & "tilápia" & 4 & - & 52.87 & - & - & - & - & - & 0.98 & - & & 46.15 \\
\hline
\end{tabular}


of the information contained in the original data matrix. The same coefficients for axes 2 (eigenvalue $=0.14$ ) and $3(0.05)$ were equal to 0.20 and 0.0 , respectively. Thus, the third axis adds little to the original data representation and was not considered in this study.

According to species and food items scores along axis 1 , species 23, 41, 46, 47, 22, 1 and 6 tended to consume items of aquatic origin, mainly detritus and plants (species scores below 150 - Figs. 3 a-b; see species codes in Table 1). On the other hand, species with scores above 150 (species 27, 28, 2, $34,50,33$ and 4) tended to consume terrestrial origin items (mainly plants and insects), and fish (species 36, 44, 42 and 43). For the species with greater scores, fish was dominant (species 13, 14, 20, 21, 39, 45, 49 and 51).

These tendencies are corroborated when species scores along axis 1 of the DCA are contrasted with the original values of the food items (Fig. 4), i.e. algae and detritus at one extreme and fish at the other. It should be emphasized that the ordination pattern of species along axis 1 of the DCA was determined mainly by these three food items. The ordination pattern of species along axis 2, was determined mainly due to aquatic insects and terrestrial plants (Fig. 5). Species 10, 12, $15,19,30$ and 52, with low scores along axis 2, tend to present higher IAi values for aquatic insects, whereas species with high scores (50, 34, 33 and 29), tend to present higher IAi values for terrestrial plants.
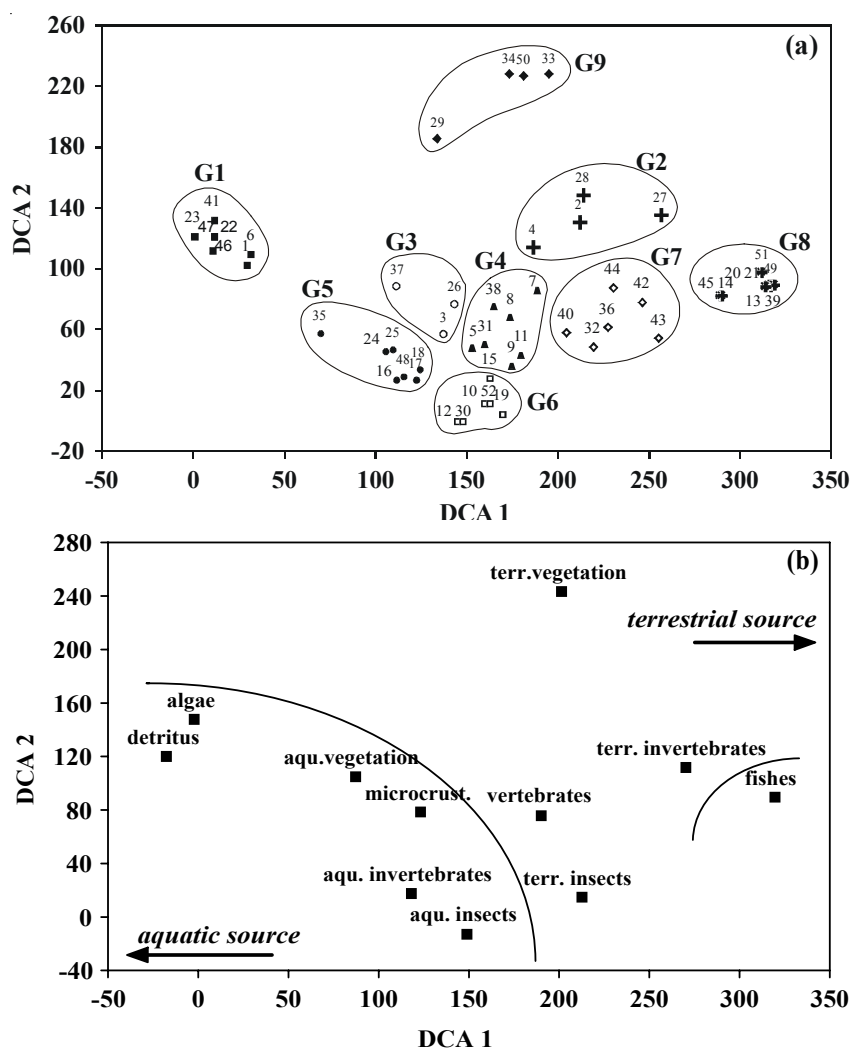

Fig. 3. Detrended correspondence analysis (DCA) scores of the species (a) and food items (b) along axes 1 and 2. Different symbols in (A) indicate the groups identified by k-means. Species are coded numerically and represented in Table 1.
Classification of the species into trophic groups. Using $k$ means analysis on the scores derived from DCA axes 1 and 2, it was possible to discriminate nine groups of species with similar diets. The $R$ statistic demonstrates that new groups did not significantly reduce $(P=0.09)$ the variance within groups, revealing that nine seems to be the most parsimonious number of groups for the data collection (Table 2). The nine groups are presented in Table 1. The species scores, along axes 1 and 2 of the DCA (Fig. 3a), are symbolized differently with the objective of better visualizing the nine groups.

The nine groups are distinguished by the following characteristics:

Group 01 - detritivores: seven species (13.4\% of the species analyzed) that exploit predominantly the bottom, ingesting large quantities of detritus/sediment (IAi $>70 \%$ ), together with algae, aquatic insect larvae, fragments of adult insects and plants, and other benthic invertebrates.

Group 02 - herbivore-piscivores: four species (7.7\%) that consume plants (predominantly), fish and insects.

Group 03 - insectivore-herbivores: three species (5.7\%) that ingest large quantities of larvae or nymphs of insects, together with algae (mainly filamentous) and plants.

Group 04 - omnivores: seven species (13.4\%) whose consumption ranges from algae (unicellular and filamentous) to

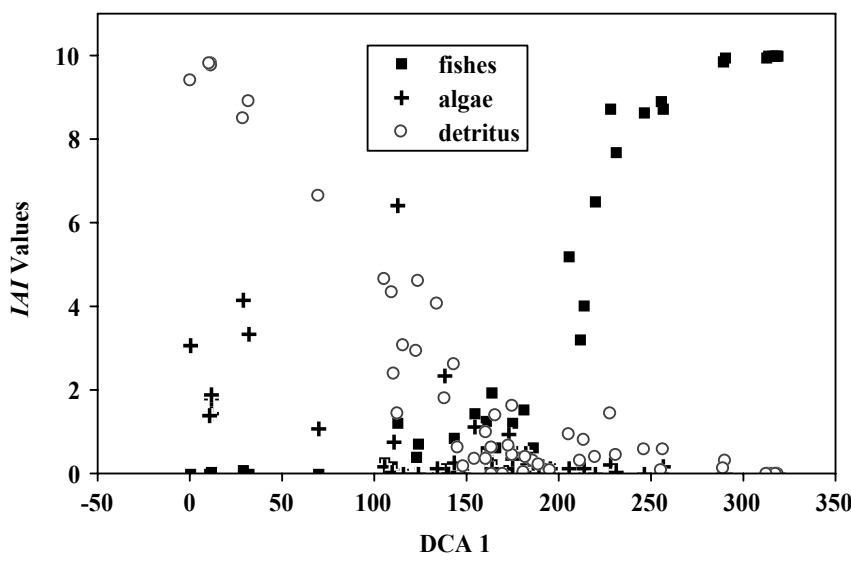

Fig. 4. Relationship between square-root transformed IAi values for fish, algae and detritus and DCA axis 1 .

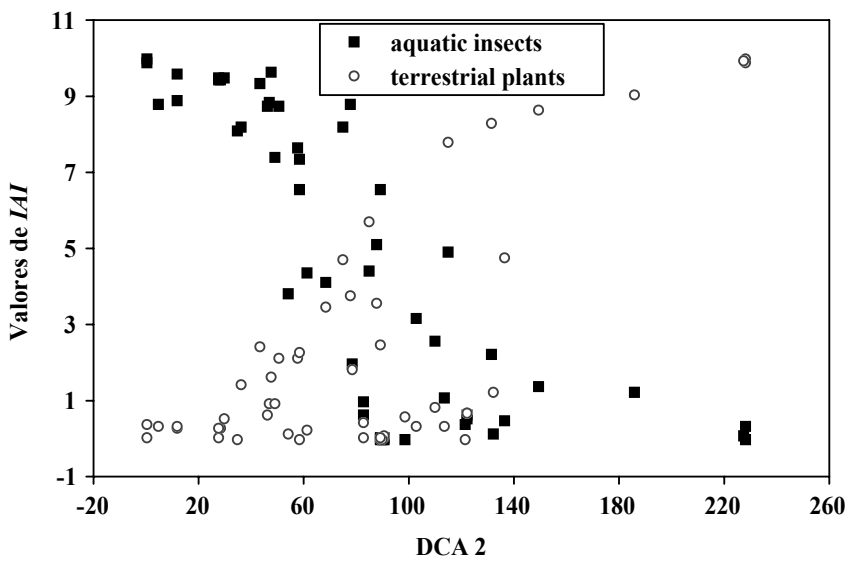

Fig. 5. Relationship between square-root transformed IAi values for aquatic and terrestrial insets and DCA axis 2. 
Table 2. Results used to calculate the $R$ statistic, which evaluates if the increase from $k$ to $k+1$ groups is significant. SQ Within $=$ Total sum of squares within; $n=$ number of species (objects); $n-k-1=$ degrees of freedom; $P=$ probability of type I error.

\begin{tabular}{lcccccc}
\hline $\begin{array}{c}\text { Number of SQ-within } \\
\text { groups }\end{array}$ & $\boldsymbol{k}$ & $\boldsymbol{n}$ & $\boldsymbol{n}-\boldsymbol{k}-\boldsymbol{1}$ & $\boldsymbol{R}$ & $\boldsymbol{P}$ \\
\hline $2 \mathrm{p} / 3$ & 284425.77 & 2 & 52 & 49 & 18.91 & 0.00000 \\
$3 \mathrm{p} / 4$ & 205224.04 & 3 & 52 & 48 & 70.99 & 0.00000 \\
$4 \mathrm{p} / 5$ & 82787.27 & 4 & 52 & 47 & 23.19 & 0.00000 \\
$5 \mathrm{p} / 6$ & 55434.09 & 5 & 52 & 46 & 16.03 & 0.00001 \\
$6 \mathrm{p} / 7$ & 41107.54 & 6 & 52 & 45 & 10.36 & 0.00020 \\
$7 \mathrm{p} / 8$ & 33415.02 & 7 & 52 & 44 & 10.48 & 0.00019 \\
$8 \mathrm{p} / 9$ & 26985.92 & 8 & 52 & 43 & 16.05 & 0.00001 \\
$9 \mathrm{p} / 10$ & 19652.61 & 9 & 52 & 42 & 2.54 & 0.09120 \\
$10 \mathrm{p} / 11$ & 18533.30 & 10 & 52 & 41 & & \\
& 14981.56 & 11 & 52 & 40 & & \\
\hline
\end{tabular}

higher plants, and from invertebrates to fish. However, they ingest preferentially aquatic and terrestrial insects.

Group 05 - invertivores: seven species (13.4\%) that are bottom feeders, ingesting organisms from the benthic fauna. In this category, the item "fish" refers to scales. Aquatic insects are the most important item for these species ( $>55 \%)$, together with detritus/sediment.

Group 06 - aquatic insectivores: six species (11.6\%) that ingest predominantly aquatic insects $(>77 \%)$, especially larvae and nymphs, with emphasis on diptera larvae. They present low incidence of detritus/sediment in the contents.

Group 07 - piscivore-insectivores: six species (11.6\%) whose diets are dominated by fish and insects (especially aquatic). Group 08 - piscivores: eight species (15.5\%) that intake essentially fish (>96\%). They can complement their diets with insects, plants and other invertebrates, but at very low proportions.

Group 09 - herbivores: four species (7.7\%) that feed essentially on plant parts $(>98 \%)$, especially terrestrial $(>82 \%)$.

\section{Discussion}

In general, fish species are endowed with great diet plasticity. This fact is easily observed when we compare information originating from different biotopes (Agostinho et al., 1997; Gaspar da Luz \& Okada, 1999) or from the same biotope in different ontogenetic phases (Hahn et al., 1997b) or periods (Fugi, 1998; Hahn et al., 1997a). Ontogenetic changes in the diet and the opportunist behavior of many fish species in consuming alternate food resources in the absence of preferential food have been the object of broad discussion in the literature (Nikolsky, 1963; Keast, 1977; Dill, 1983; Gerking, 1994). According to Gerking (1994), when there is a shortage of a certain preferential resource (for example, due to environmental conditions), most fish species can intake temporarily the more available resource. Lowe-McConnell (1999) relates a similar fact to tropical fish species. Given the alimentary flexibility exhibited by fishes, it is important that investigations regarding species diet spectrum are based on all life stages over a wide spatial and temporal scales. Although this study investigates only part of the total distribution area of most of the species, the fact that it covers wide ontogenetic, seasonal and biotopic variations, should give more realistic results.

Most of the species examined in this study presented a wide alimentary spectrum. Thirty-five percent varied their diets eating items as different as fish, algae, higher plants, insects and detritus. Among the identified trophic groups, only piscivores and herbivores were restrictive in relation to the items ingested.

The incorporation of terrestrial insects caused by sudden variation in water level of the reservoir should determine the wide availability of this resource. Complementally, the large number of small-sized species and the abundance of juveniles of large-sized species (with other feeding preferences as adults) should be related to the wide occurrence of this item in the diet.

Terrestrial plants were common in the diet of the species (74\%) and represented a substantial amount of the biomass ingested, especially in biotopes outside of the reservoir. The lower availability of terrestrial plants in the dammed area, when compared to other environments, could be due to the fact that samplings for this analysis began six months after damming, when younger plant parts (preferentially consumed by fishes) had already decomposed. Water level fluctuation, which limited the development of terrestrial and riparian vegetation in the reservoir zone, is a barrier for the availability of this resource.

The resource "fish", present in the diet of $64 \%$ species, had the greatest availability in all habitats, except streams. This result can be partially explained by population explosions of forage fish species, as a result of increased availability of food resources provided by the flooding of large terrestrial areas and the period of dam closure. So, the formation of Corumba reservoir, impounded in September 1997, overlapped with the reproductive period of many forage species. Besides this, during reservoir filling, a high amount of terrestrial organic matter is incorporated in the aquatic system resulting in a marked increase in the availability of food resources that can be ingested by small-sized and opportunists species (Agostinho et al., 1999). As a consequence of the proliferation of these species, there is an increase in piscivores. The fact that the availability of fish, inferred from the stomach contents volume of all species, surpassed plants and detritus for most of the biotopes considered, results from the partial approach of the food web, which is restricted to fish and, even so, excludes the larval and juvenile phases (generally with lower positions in the food web).

The analysis of food resources for the streams shows that items of allochthonous origin are predominant, especially terrestrial insects and plants. This result confirms the great interaction of aquatic communities with the terrestrial environment in streams (Knoppel, 1970; Welcomme, 1985; 
Lowe-McConnell, 1999; Araújo-Lima et al., 1995). However, various studies indicated the great importance of attached algae and aquatic larvae of insects (Teixeira, 1989; Henderson \& Walker, 1990; Sabino \& Castro, 1990; Lowe-McConnell, 1991). Thus, the relative importance of allochthonous and autochthonous foods for stream fish assemblages may be dependent on the environmental conditions of the specific stream studied (e.g. amount of vegetation cover in the watershed, water transparency and velocity, etc.).

The instability of a recently dammed environment, with resources that are both qualitatively and quantitatively unusual, is a strong source of bias when one tries to characterize trophic groups. Even so, the multivariate analysis based on food resources discriminated the groups that used terrestrial, aquatic and fish along the gradient.

The fish assemblage of Corumbá reservoir species presented high diet plasticity, except for a small group of herbivores and detritivores, which are characterized by marked morphological adaptations that may restrict the use of other resources. This indicates that diet studies carried out under variable environmental conditions (e.g. along a riverine-lacustrine gradient) are efficient in revealing the amplitude of the alimentary spectrum of species that do not present marked morphological restriction. This was not the case for a restricted group of piscivores that consumed fish almost exclusively, but do not show morphological restrictions in taking other small items like insects and other invertebrates, as described by studies in different areas of the Paraná river basin (Almeida et al., 1997; Penczak et al., 2000).

In new formed reservoirs, the high heterogeneity of food resources provides an excellent opportunity to evaluate diet plasticity of fishes. However, in the phase that the Corumbá reservoir is, it was difficult to set up reliable species preferences (patterns), and, therefore, to put them in trophic categories, even using the ordination and classification methods employed in this study. This plasticity appears to be important in determining species success in reservoirs.

\section{Acknowledgements}

We are grateful to Nupélia/UEM and FURNAS Centrais Elétricas for supporting this study, to CNPq for the grant, to Luiz Carlos Gomes, David J. Hoeinghaus (Texas A\&M University) and John Jervis for reviewing the English.

\section{Literature Cited}

Agostinho, A. A. 1992. Manejo de recursos pesqueiros em reservatórios. Pp.106-121. In: Agostinho, A. A. \& E. Benedito-Cecilio (Eds.). Situação atual e perspectivas da Ictiologia no Brasil. EDUEM, Maringá, 127p.

Agostinho, A. A., A. E. A. M. Vazzoler, \& S. M. Thomaz. 1995. The High river Paraná basin: limnological and ichthyological aspects. Pp.59-103. In: Tundisi, J. G., C. E. M. Bicudo \& T. Matsumura-Tundisi (Eds.). Limnology in Brazil. ABC/SBL, Rio de Janeiro, 376p.
Agostinho, A. A., C. M. L. Ferretti, L.C. Gomes, N. S. Hahn, H. I. Suzuki, R. Fugi \& F. Abujanra. 1997. Ictiofauna de dois reservatórios do rio Iguaçu em diferentes fases de colonização: Segredo e Foz do Areia. Pp. 257-292. In: Agostinho, A. A. \& L. C. Gomes (Eds.). Reservatório de Segredo: bases ecológicas para o manejo. EDUEM, Maringá, 387p.

Agostinho, A. A., L. E. Miranda, L. M. Bini, L.C. Gomes, S. M. Thomaz \& H. I. Suzuki. 1999. Patterns of colonization in neotropical reservoirs, and prognoses on aging. Pp. 227-265. In: Tundisi, J. G. \& M, Straskraba (Eds.). Theoretical reservoir ecology and its applications. Backhuys Publishers, Leiden, 585p.

Almeida, V. L. L., N. S. Hahn \& A. E. A. M.Vazzoler. 1997. Feeding patterns in five predatory fishes of the high Paraná river floodplain (PR, Brazil). Ecology of Freshwater Fish, 6: 123-133.

Araújo-Lima, C. A. R. M., A. A. Agostinho \& N. N. Fabré. 1995 Trophic aspects of fish communities in brazilian rivers and reservoirs. Pp.105-136. In: Tundisi, J. G., C. E. M. Bicudo \& T. Matsumura-Tundisi (Eds.). Limnology in Brazil. ABC/SBL, Rio de Janeiro, 376p.

Bussab, W. O., E. S. Miazaki \& D. F. Andrade. 1990. Introdução à análise de agrupamentos. Simpósio Brasileiro de Probabilidade e Estatística, IME-USP, São Paulo, 105p.

Dill, L. M. 1983. Adaptive flexibility in the foraging behaviour of fishes. Canadian Journal Fisheries Aquatic Sciences, 40: 398-408.

Fugi, R. 1998. Ecologia alimentar de espécies endêmicas de lambaris do trecho médio da bacia do rio Iguaçu. Unpublished Ph.D. Thesis, Universidade Federal de São Carlos, São Paulo. 88p.

Gauch, H. G., Jr. 1994. Multivariate analysis in community ecology. Cambridge, Cambridge University Press, 298p.

Gaspar da Luz, K. D. \& E. K. Okada. 1999. Diet and dietary overlap of three sympatric fish species in lakes of the upper Paraná river floodplain. Brazilian Archives of Biology and Technology, 42: 441-447.

Gerking, S. D. 1994. Feeding ecology of fish. San Diego, Califórnia, Academic Press, 416p.

Hahn, N. S., R. Fugi, V. L. L. Almeida, M. R. Russo \& V. E. Loureiro. 1997a. Dieta e atividade alimentar de peixes do reservatório de Segredo. Pp.141-162. In: Agostinho, A. A. \& L. C. Gomes (eds.). Reservatório de Segredo: bases ecológicas para o manejo. EDUEM, Maringá, 387p.

Hahn, N. S., A. A. Agostinho \& R. Goitein. 1997b. Feeding ecology of curvina Plagioscion squamosissimus (Hechel, 1840) (Osteichthyes, Perciformes) in the Itaipu reservoir and Porto Rico floodplain. Acta Limnologica Brasiliensia, 9: 11-22.

Henderson, P. A. \& I. Walker. 1990. Spatial organization and population density of the fish community of the litter banks within a Central Amazonian blackwater stream. Journal of Fish Biology, 37: 401-411.

Hill, M. O. \& H. G. Gauch. 1980. Detrended correspondence analysis: an improved ordination technique, Vegetatio, 42: 47-58.

Hynes, H. B. N. 1950. The food of freshwater sticklebacks (Gasterosteus aculeatus and Pygosteus pungitius), with a review of methods used in studies of the food of fishes. Journal of Animal Ecology, 19: 36-58.

Hyslop, E. J. 1980. Stomach contents analysis, a review of methods and their application. Journal of Fish Biology, 17: 411-429.

Kawakami, E. \& G. Vazzoler. 1980. Método gráfico e estimativa de índice alimentar aplicado no estudo de alimentação de peixes. Boletim do Instituto Oceanográfico 29: 205-207.

Keast, A. 1977. Mechanisms expanding niches width and minimising intraspecific competition in two centrarchid fishes. Evolutionary Biology, 10: 333-395. 
Knoppel, H. A. 1970. Food of Central Amazonian fishes. Contribution to the nutrient ecology of Amazonian rain forest streams. Amazoniana, 2: 257-352.

Lawlor, L. R. 1980. Overlap, similarity, and competition coefficients, Ecology 61: 245-251.

Lowe-Mcconnell, R. H. 1991. Natural history of fishes in Araguaia and Xingu Amazonian tributaries, Serra do Roncador, Mato Grosso, Brazil. Ichthyological Exploration of Freshwaters, 2: 63-82.

Lowe-McConnell, R. H. 1999. Estudos ecológicos de comunidades de peixes tropicais.Editora da USP, São Paulo, 535p.

Nikolsky, G. V. 1963. The ecology of fishes. Academic Press, London, 352p.

Paiva, M. P. 1982. Grandes represas do Brasil. Brasília: Editerra. 292p.

Paiva, M. P. 1983. Peixes e pescas de águas interiores do Brasil. Brasília: Editerra, 1983.

Penczak, T., A. A. Agostinho \& N. S. Hahn. 2000. An ordination technique for fish diet comparisons. Brazilian Archives of Biology and Technology 43: 101-110.

Petrere, M. \& M. C. L. B Ribeiro. 1994. The impact of a large tropical hydroelectric dam: the case of Tucurui in the middle river Tocantins. Acta Limnológica Brasiliensia, 5: 123-133.

Petts, G. E. 1984. Impounded rivers: perspectives for ecological management. John Wiley \& Sons, Chichester, 326p.

Rodrigues-Ruiz, A. 1998. Fish species composition before and after construction of a reservoir on the Guadalete river (SW Spain). Archive für Hydrobiologie, 142: 353-369.
Sabino, J. \& R. M. C. Castro. 1990. Alimentação, período de atividade e distribuição espacial dos peixes de um riacho da floresta Atlântica (Sudeste do Brasil). Revista Brasileira de Biologia, 50: 23-36.

Stasoft, Inc. 2000. STATISTICA for Windows (Computer Program Manual). Version 5.5, Tulsa, OK.

Teixeira, R. L. 1989. Aspectos da ecologia de alguns peixes do arroio Bom Jardim, Triunfo, RS. Revista Brasileira de Biologia, Rio de Janeiro, 49(1): 183-192.

Welcomme, R. L. 1985. River fisheries. FAO Fisheries Technical Paper, $\mathrm{n}^{\circ} .262$.

Winemiller, K. O. 1986. Dynamic diversity in fish assemblages of tropical rivers. In: Cody, M. L. \& R. Smallwood (Eds.). Longterm studies of vertebrate communities. Orlando, Florida: Academia Press, 99-134.

Winemiller, K. O. 1989. Ontogenetic diet shifts and resource partitioning among piscivorous fishes in the Venezuelan Ilanos. Environmental Biology of Fishes, 26 (1): 177-199.

Winemiller, K. O. \& L. C. Kelso-Winemiller. 1996. Comparative ecology of catfishes of the upper Zambezi river floodplain. Journal of Fish Biology, 49 (6): 1043-1061.

Received April 2005

Accepted October 2005 